\title{
Fisheries and the Farne Islands Grey Seals
}

\section{BY GRACE HICKLING}

Last December the Ministry of Agriculture and Fisheries made a cull of the grey seals on the Farne Islands, which brought a storm of protest from the general public. Mrs. Hickling, authority on the seals and a member of the Farne Islands management committee of the National Trust, tells why the decision was made, and traces the history of the fishermen-seal controversy since the previous cull in 1958.

O

N 3rd December, 1958, ten grey seal calves were killed on the North Wamses, a small island some three miles off the north Northumberland coast. This was the first licensed killing of grey seals during the breeding season since the passing of the 1932 Grey Seals Protection Act and it was intended to be the first stage of an experimental annual cull of 300 calves, recommended as a means of reducing the grey seal population of the Farne Islands and thereby lessening the damage done by seals to the salmon fishing industry. This initial cull, the events that preceded it, and the protests that followed were fully described in ORYX (Vol. V, No. 1, April, 1959) and the present article deals with subsequent developments.

Before 1958, most of the complaints of seal damage came from the salmon fishermen of the north Northumberland coast and the River Tweed, although between December, 1951 (when numbered tags were first used to mark young grey seals), and December, 1958, eight Farne-marked calves were recovered in fishing nets on the east coast of Scotland. Two of these were in cod nets and the remainder in salmon nets.

Since then the record catches of Tweed salmon and the high dividends paid by the Berwick Salmon Fisheries Company made it more difficult to substantiate complaints of large-scale seal damage, although the subject was never completely forgotten. The Tweed authorities were, however, much more concerned, first with the Seahouses fishermen's attempts to have the Tweed Act (which bans inshore fishing for salmon within five miles of the river) repealed and, second, with the effect on salmon stocks of the ever-increasing practice of drift netting for salmon. Indeed, it was not until September, 1962, when drift netting was banned, that the seals again came into prominence, although, strangely enough, the ban brought popularity to the seals, at least among some of the Seahouses fishermen, who took the view that, if they could not catch salmon, the more the seals got the better! On the other hand, complaints of damage to white fishing increased steadily, and they came from as far south as Yorkshire where the finding in fishing nets of two seals known definitely to have come from the Farnes led to demands for a drastic reduction in the size of the colony. At the same time there was a marked increase in complaints from the 


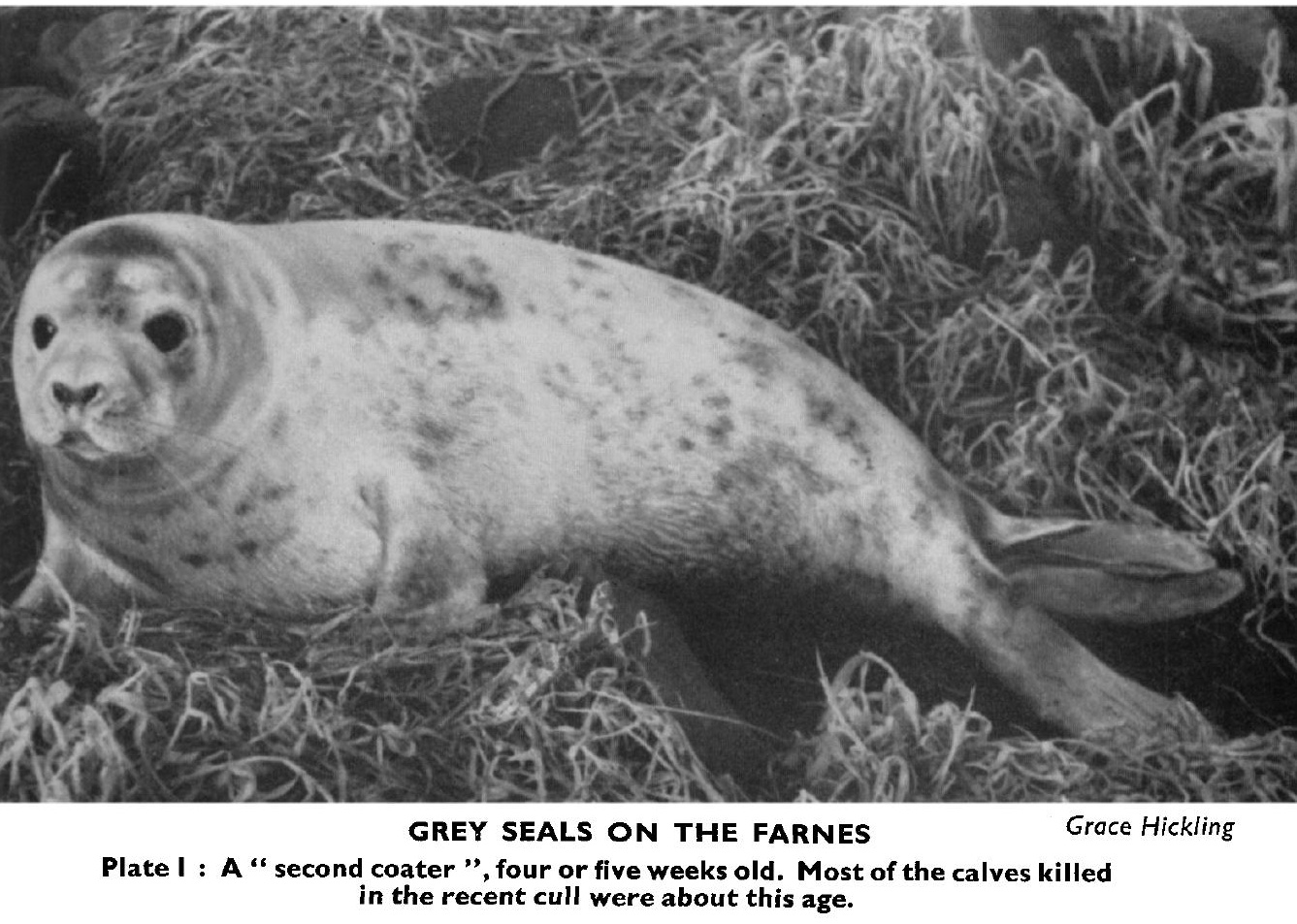
in the recent cull were about this age.

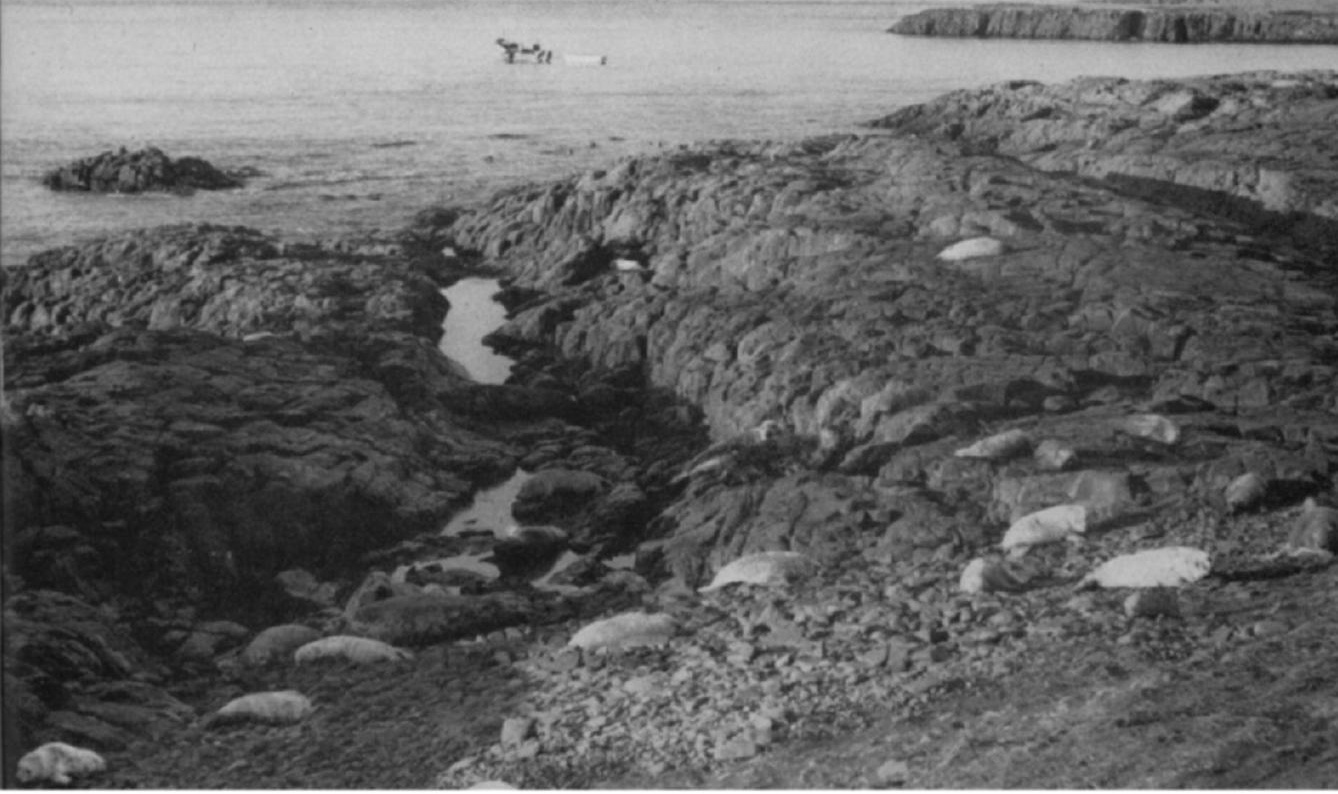
killed here than on any other island. 


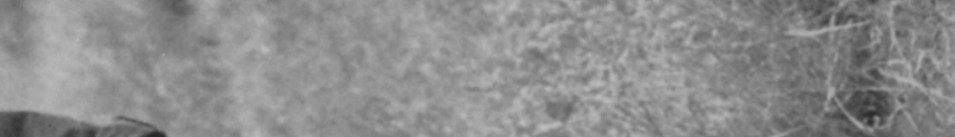




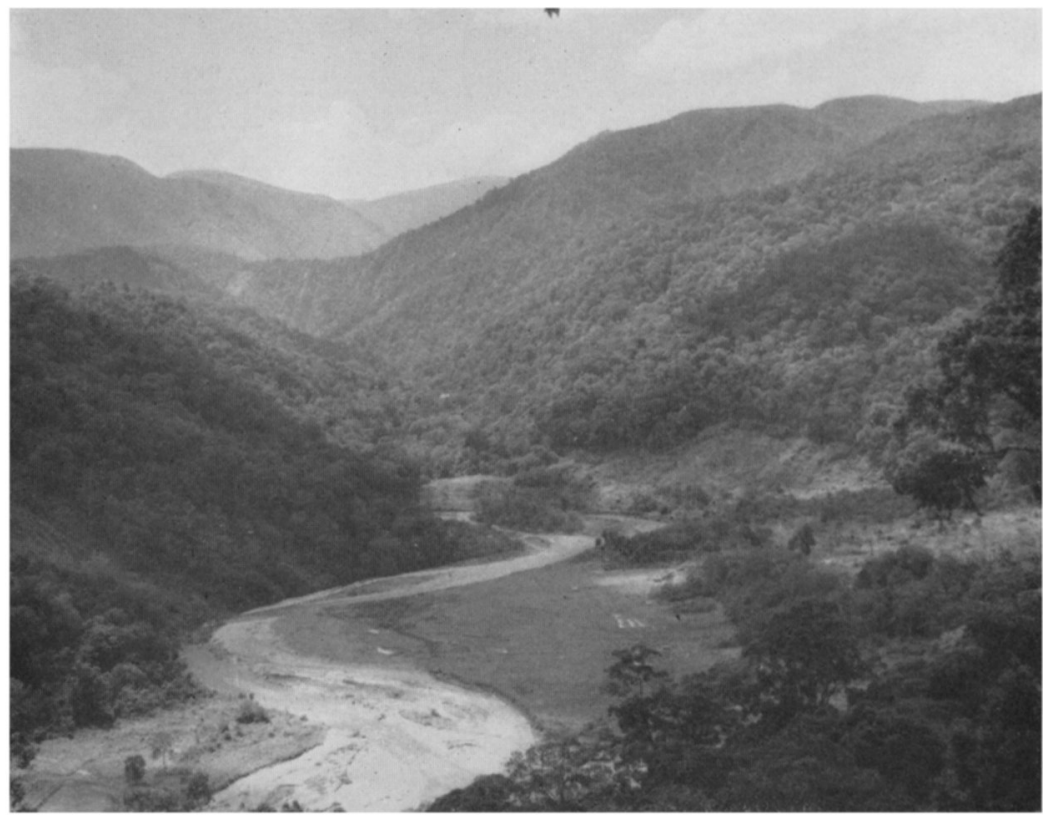

Plate 5 : Habitat of the orang-utan. The Loser Reserve in North Sumatra and the Alas River.

Photographs by Oliver Milton

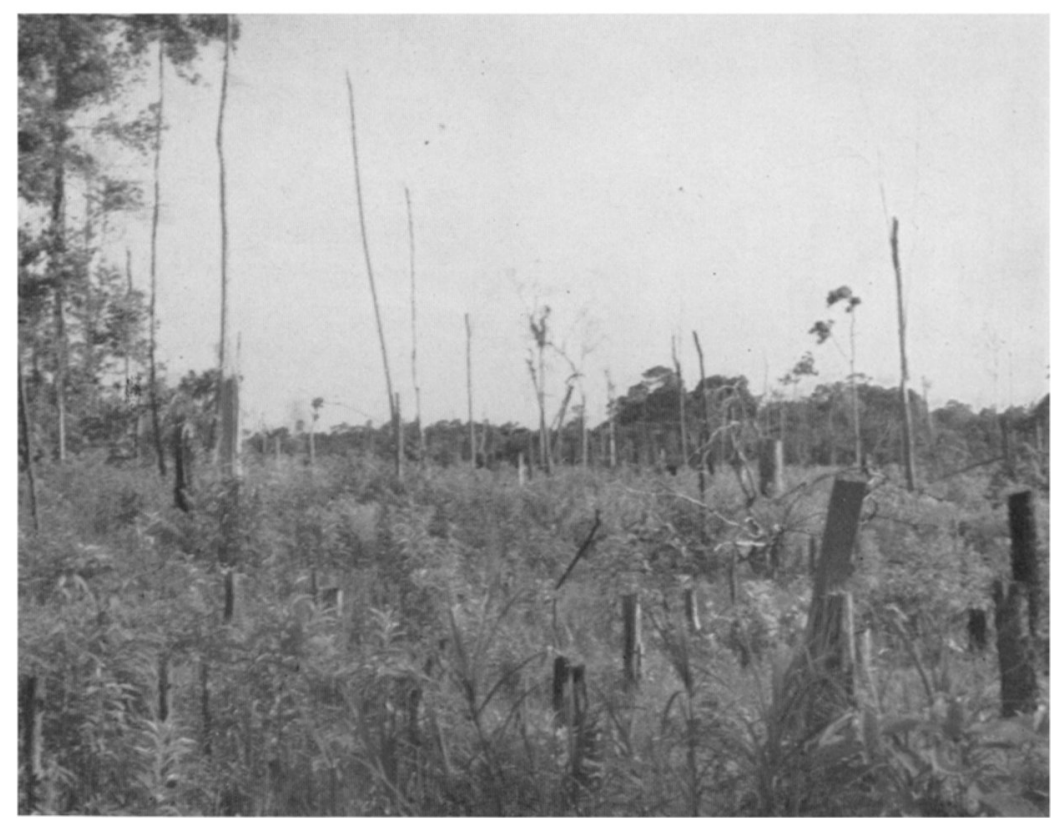

Plate 6: Once the habitat of the rhinoceros. Central Sumatra, near Pekanbaru. Four years ago this was dense forest. 


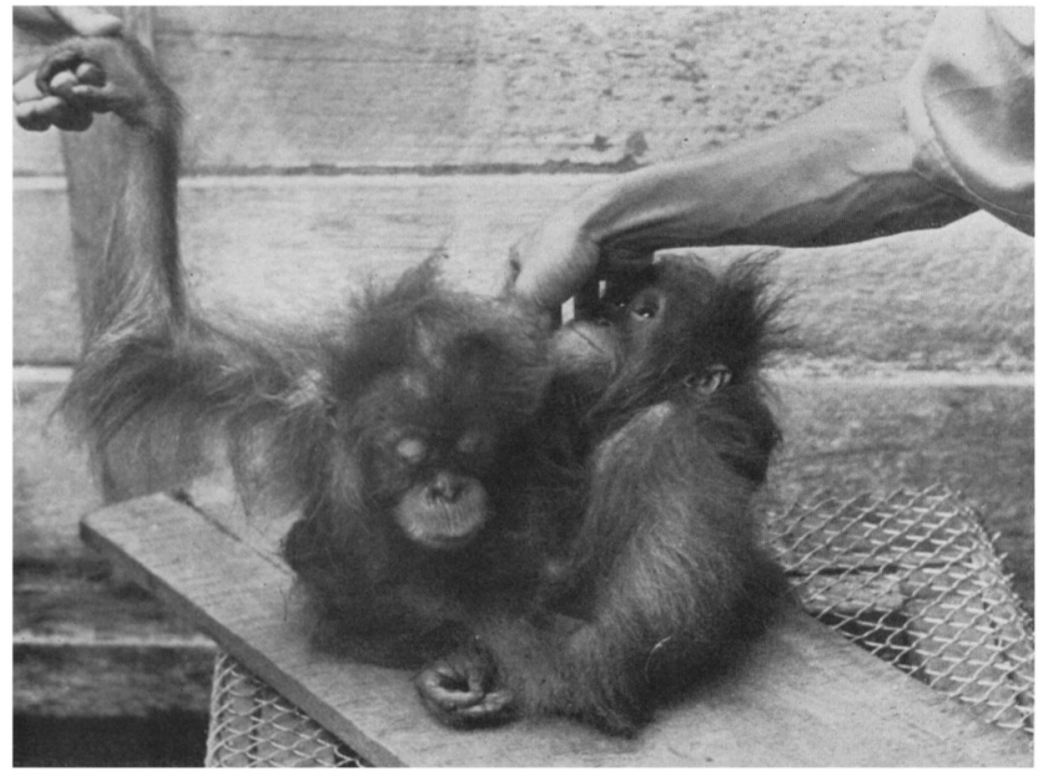

Plate 7 : Two miserable baby orang-utans smuggled into Singapore and waiting to be smuggled out.

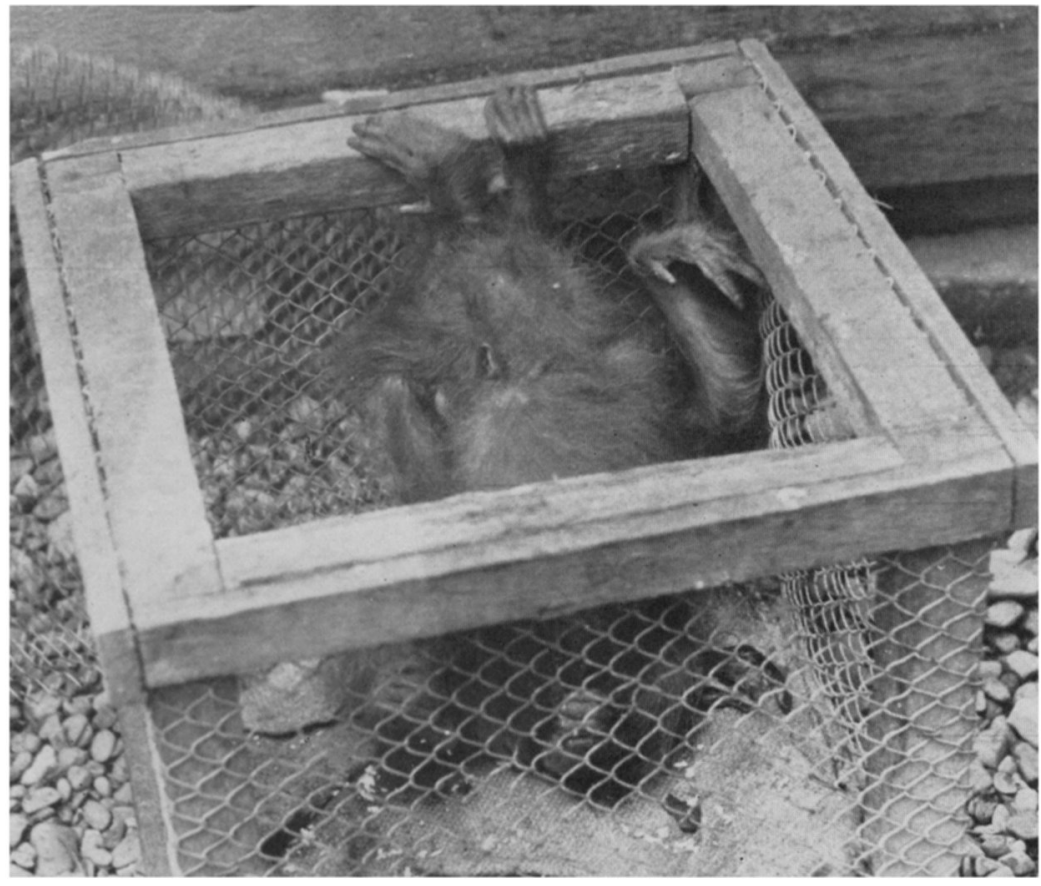

Plate 8: "In a box so small that they had to spend the whole time in a crouched position..." See article on page I77. 


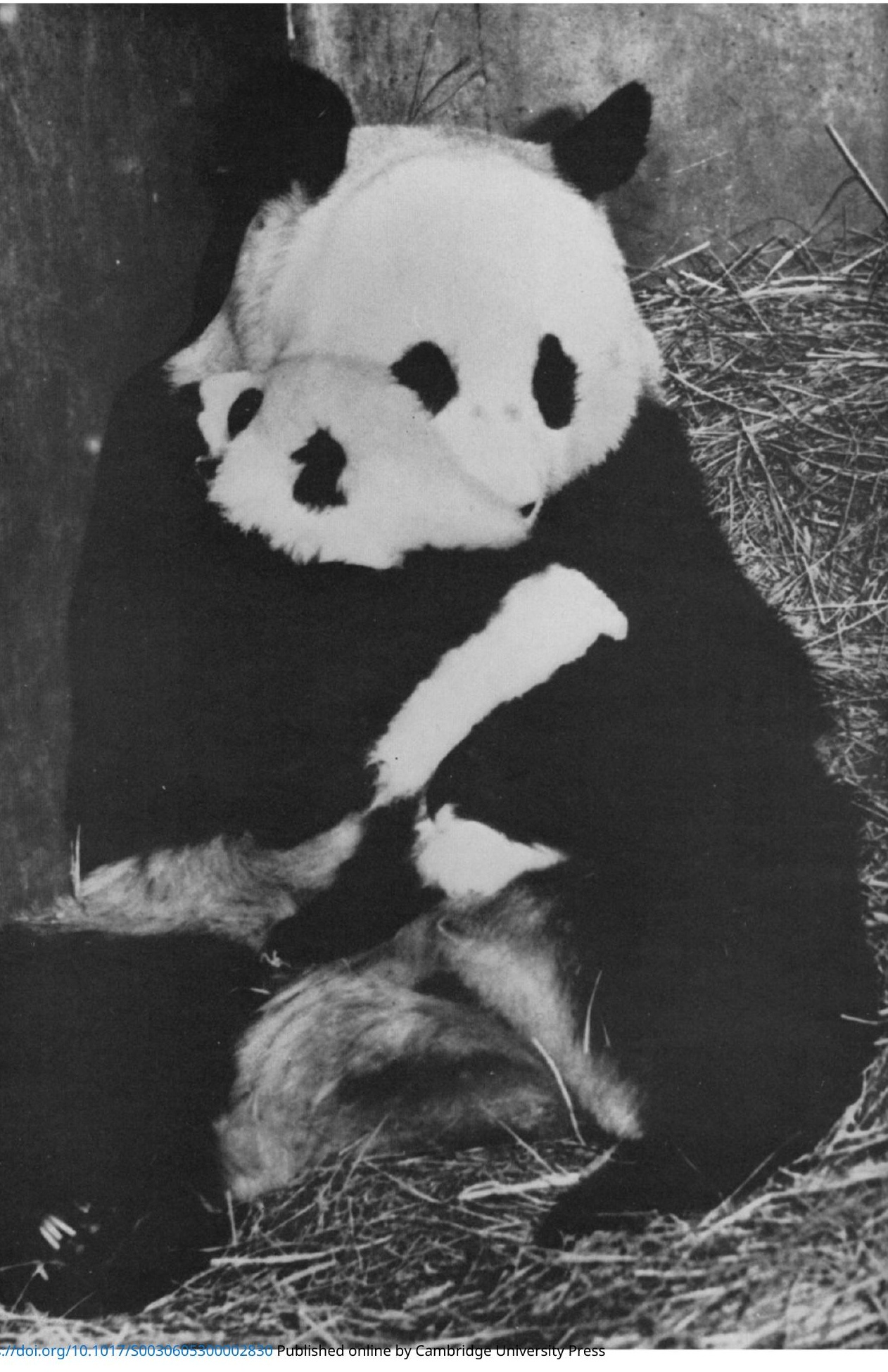




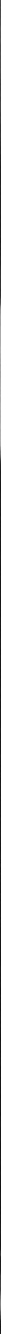

Plate 10 above: The first giant panda bred in captivity was born last autumn in Pekin Zoo. News of the birth of the baby was picked up by the BBC monitoring service and passed to the World Wildlife Fund. Peter Scott, chairman of the British National Appeal, sent a cable of congratulations to the Director of the Zoo and asked for photographs. He received a cable of thanks in reply and the photographs followed. They are reproduced here by courtesy of the World Wildlife Fund.

Plate 9 (left) : The Bear Hug. The baby giant panda with its mother in https://doi.org/10.1017/S0030605300002830 PublisPelciminZlo,óambridge University Press 
north-east coast of Scotland. Here the salmon companies reported extensive damage by seals, not only to fish but, more important, to nets. Seals from the Farnes, the majority under a year old, were recovered from the nets, while others were shot nearby. Moreover, scientific examination of seal stomachs showed that, in at least some cases, the animals had undoubtedly been feeding on salmon shortly before their deaths.

The public outcry which followed the 1958 killing had led to the abandonment of the projected cull, and no further orders amending the Grey Seals Protection Act in respect of the Farne Islands were made. Nevertheless, the problem remained, and in 1959 a new and intensified programme of research was started. This was made possible by a grant from the Development Commission; in addition to financing work already being carried out by amateur bodies such as the Natural History Society of Northumberland, Durham and Newcastle upon Tyne and the West Wales Field Society, a full-time research zoologist, Mr. E. A. Smith, was appointed. Simultaneously, a Consultative Committee on Grey Seals and Fisheries was set up under the chairmanship of Dr. E. B. Worthington of the Nature Conservancy; its other members were Dr. C. E. Lucas (Department of Agriculture and Fisheries for Scotland), Mr. F. T. K. Pentelow (Ministry of Agriculture, Fisheries, and Food), Dr. L. Harrison Matthews (Zoological Society of London), ${ }^{\star}$ Dr. R. M. Laws (National Institute of Oceanography), and Capt. J. de B. Stansfeld (Association of Scottish District Salmon Fishery Boards).

\section{Cropping Recommended}

The Committee's report $\dagger$ was approved by the Nature Conservancy and appeared in March, 1963. It covered the population, range of movements, breeding biology, and food of grey seals, with a section on the effect of seals on fishing gear and fish catches, and several supporting papers treating the results of research in greater detail. Among its recommendations for the management and control of grey seals in Great Britain the Committee proposed that the cropping of grey seals in the Orkney Islands, first started in 1959, be continued and that control measures be started on the Farne Islands. In both these areas the aim should be to reduce, during the next five years, the breeding potential of the colony by one-quarter. This meant that the number of calves born annually on the Farnes (estimated in the report to be approximately 1,000 ) must, at the end of five years, be reduced to 750 . It was suggested that this could be achieved by making an annual kill of eighty-five pregnant cows (or cows with calves) or an equivalent number of female calves. On this basis, four female calves were considered to equal one cow and it was thought that, in practice, the cull would probably be a mixed one.

Culling carried out in Orkney between 1959 and 1962 caused considerable concern among local naturalists who feared that commercial interests might encourage exploitation of the seals and so lead to a disregard of the

* Dr. Laws was unable to attend the later meetings owing to absence abroad.

$\dagger$ Grey Seals and Fisheries. Report of the Consultative Committee on Grey Seals and Fisheries. London, H.M.S.O. (Nature Conservancy, 1963). 4s. 6d. Reviewed on page 185. 
official annual quota of animals to be killed. But Orkney is remote, and few people in England, or on the Scottish mainland, knew anything of this operation (which took the form of commercial seal hunting). It was not until 17th December, 1963, when the Secretary of State for Scotland admitted that the 1963 target figure of 750 calves had been exceeded by 244, that there was widespread public alarm.

Conditions on the Farne Islands are very different. Not only do the islands belong to the National Trust, but they are a world-famous nature reserve and the place where, some 1,300 years ago, St. Cuthbert started the first scheme for the protection of wild life. All this means that both birds and seals are seen each year, under ideal conditions, by large numbers of the public-indeed the Farne Islands are the only place in the British Isles where, in winter, given reasonable luck, the ordinary visitor can watch at close quarters the breeding behaviour of a grey seal colony. The administration of the islands is in the hands of the Farne Islands Local Committee of the National Trust, and for several years the seals have been an ever-present problem. On the one hand was the knowledge that killing on the islands might well destroy the unique character of the colony, in particular the amazing tameness of the adults. On the other, was the realization that, if it was clearly established that the Farne seals were a menace to fishing interests (both salmon and white fish), measures must be taken to protect the livelihood of the people affected.

\section{Conditional Agreement to the Cull}

In addition to the protection given by the National Trust, the 1932 Grey Seals Protection Act makes it illegal to take, wound, or kill a grey seal between 1st September and 31st December. Accordingly, before any seals could be killed on the Farnes during the breeding season, a draft Order suspending the Act had to be laid before each House of Parliament for not less than forty days and only after the expiration of that time could an effective Order be made. It was realized that the proposed Order might well give rise to considerable criticism, but members of the Local Committee felt that, following the publication of the report, and despite many regrets, they could no longer oppose the suggested cull. They emphasized, however, that they regarded the cull as experimental and that their acquiescence did not extend beyond the proposed five-year period. They insisted, too, that there must be no commercial exploitation of the seals and that the killing should be carried out in such a way as to cause the minimum of disturbance to the rest of the colony. Incidentally, although the Natural History Society of Northumberland, Durham and Newcastle upon Tyne has no direct responsibility for the management of the Farnes, the Council of the Society has kept in close touch with the Local Committee and it, too, decided, albeit reluctantly, not to oppose a trial cull.

In June, 1963, a joint meeting of the Consultative Committee and the Local Committee of the National Trust was held in Newcastle, representatives of the Natural History Society and of the Northumberland and Durham Naturalists' Trust being present as observers. All aspects of the cull were thoroughly discussed and among the points made by the Local Committee were that there must be regular reports on its effect on the 
damage done by seals to fisheries, that at least one island should, if possible, be left undisturbed and that research on the colony must continue. Following this discussion a draft Order was laid on 17th July and this became effective on 4th December; it will remain in operation for twelve months. Despite expectations, there were practically no protests. A few individuals wrote letters to the newspapers, but there were no questions in Parliament and the only organization to question the decision was the Northern Federation of Sea Angling Societies, whose secretary stated, on 16th August, that the grey seal was being turned into a scapegoat for the failings of the fishing industry as a whole. There is no doubt that it was largely because of this apparent apathy that the publicity given to the actual killing and the adverse criticism it engendered came as such a surprise to many people.

\section{Officials Present}

All arrangements for the cull were made by the Ministry of Agriculture, Fisheries, and Food and, in order to ensure that nothing went wrong, one of the Ministry's most senior officers was on the islands for most of the time. Neither the Nature Conservancy nor the National Trust took any part, although an observer from the Trust was present throughout. The remainder of the party consisted of three other Ministry officials (one a veterinary officer), two marksmen, and an RSPCA inspector. Owing to persistently stormy weather in November it was realized that it might be impossible to reach the islands by boat and, accordingly, arrangements were made to use a BEA helicopter. Killing took place on Staple Island (145 calves shot and two killed by injection) on 5th December, on North Wamses (100 calves shot) and South Wamses (twenty-three calves and one cow shot) on 6th December, and on the north end of Brownsman (73 calves shot) on the morning of 7th December. In addition, four calves were removed to a zoo. With the exception of two animals killed by an injection of Nembutal, all the calves were shot with a Webley Scott - 32 humane killer (veterinary pistol) held a few inches from the back of the animal's head. Injection was effective, but the animal took some time to die, whereas in practically all cases shooting resulted in instantaneous death. A - 303 rifle was used to kill the cow. All the calves were sexed and, although there were a few mistakes, most of those killed were females.

\section{Other Seals Undisturbed}

It had originally been expected that the killing would be carried out towards the end of November and the delay in making the Order meant that many calves had already left the islands while the majority of those still there were weaned-i.e. over three weeks old. This had certain definite advantages-for example, there was much less risk of causing distress to the cows-but it also meant that it was impossible to leave even one island undisturbed. It should, however, be emphasized that the actual shooting had very little effect on other members of the colony. Some of the calves flinched at the sound of the shot, but the sight of the dead bodies did not seem to upset them. One bull and cow continued mating, quite undisturbed, only 20 yards away from a place where several calves 
were shot. Most of the disturbance was due to the presence of humans and this undoubtedly caused some of the second coaters to enter the sea prematurely although fortunately, at this age, they would take little harm and, indeed, would probably haul out on a neighbouring island.

The Local Committee had stipulated that all carcases must be removed and, accordingly, the Ministry made a contract with an Orcadian firm who proposed to sell both skins and bodies (the latter for fishmeal). This arrangement has been criticized, but it must be pointed out that the task of carrying limp corpses, weighing up to $100 \mathrm{lb}$. apiece, for considerable distances over slippery rocks, and then loading them into dinghies, is a decidedly arduous one. It is certain that unskilled labour would have been quite unable to undertake this work.

\section{Protests and Criticism}

On the Farnes, so effective was this clearing-up process that three days later the only sign of the cull was a decrease in the normal numbers of calves-other activities of the colony continued as usual. But on land the after-effects are still being felt. There have been innumerable letters in newspapers-some of them completely uninformed-while naturalists from all over the country have voiced their protests. There has been criticism, too, of the evidence on which the Consultative Committee based its recommendations and, finally, both the Tweed Commissioners and Mr. Ralph Wilson, reported leader of the inshore fishermen, have publicly denied that they were responsible for asking for the seals to be killed. There is no doubt that all the facts will be carefully re-examined before next autumn, but, whatever decision is reached, it is obvious that in the circumstances then prevailing, the National Trust had no choice but to agree to the 1963 killing. At the same time no one will be more delighted than the National Trust if it is found possible to abandon further culling in this sanctuary.

\section{THE VIEWS OF LOCAL NATURALISTS}

'THE Northumberland and Durham Naturalists' Trust has issued a statement saying that they do not consider that the case for limiting the size of the Farne Islands seal colony has been established at the present time, for the following reasons: the data available on damage to both fisheries and gear is inadequate; nothing is known about the movements of seals other than those in the first year of life; and they challenge the basis of the life-table of the grey seal given in the report. The Trust considers that the seal culling on the Farnes should cease until a definite case for reducing the numbers has been established.

The Natural History Society of Northumberland, Durham, and Newcastle upon Tyne has asked for an assurance from the chairman of the Consultative Committee on Grey Seals and Fisheries that long-term research will continue, and that he will do all in his power to provide financial assistance for the Society to ensure the continuation of its scientific investigations into the life history of the Farne seals. 